\title{
IMPACT OF COINFECTION OF PV B19 ON THE COURSE AND PROGNOSIS OF MALARIA CAUSED BY PLASMODIUM FALCIPARUM
}

\author{
I.N. Lavrentyeva ${ }^{a}$, I.V. Khamitova ${ }^{a}$, A.V. Slita ${ }^{a}$, A.E. Levkovski ${ }^{b}$, A.A. Diallo ${ }^{\text {, }}$ \\ A.K. Diallo , T.C. Sow , E.V. Naydenova ${ }^{\mathrm{c}}$, D.A. Agafonov ${ }^{\mathrm{c}}$, A.M. Senichkina ${ }^{\mathrm{c}}$ \\ ${ }^{a}$ St. Petersburg Pasteur Institute, St. Petersburg, Russian Federation \\ ${ }^{b}$ Hospital RUSAL FRIGUIA, Fria, Republic of Guinea \\ "Russian Research Anti-Plague Institute "Microbe", Saratov, Russian Federation
}

\begin{abstract}
Absract. Parvovirus infection (PVI) is widespread in the world; more than $80 \%$ of the adult population have antibodies of $\operatorname{IgG}$ class to parvovirus B19. Malaria is a vector-borne parasitic disease caused by the protozoa of the genus Plasmodium, that is widespread in the countries of Africa, Southeast Asia, Oceania. The objective of the present study was to evaluate the effect of parvovirus B19 infection on the clinical course of malaria and the outcome of the underlying disease. During the period 2016-2018 blood plasma samples of 316 patients from the hospital of the Friya Prefecture of the Republic of Guinea (GR) with confirmed diagnosis of malaria were examined for the presence of PVB19 DNA. The clinical course of malaria in 316 examined patients was divided into group of either mild or complicated. In total, PVB19 DNA was detected in blood plasma in 55 of 316 patients (17.41 $\pm 2.13 \%)$. But in the group with co-infection of PVB19 and P. falciparum complications were observed in 40 of $55(72.73 \pm 2.75 \%)$ patients, and in 6 of 55 cases $(10.91 \pm 4.40 \%)$ the disease resulted in death. In the group of patients with malaria without PVI, complications occurred in 99 of 261 patients (37.9 $\pm 3.0 \%)$; of those $2(0.77 \pm 0.54 \%)$ died. It was found that the most numerous group in the structure of malaria patients is represented by children under 5 (median 3 ) years $(89$, or $28.25 \pm 2.53 \%$ ). Our results correlate with the data of other researchers who studied the PVI-associated malaria in children in malaria-endemic regions: among children under 5 years, the absolute majority of cases of PVI was accompanied by a complicated course of malaria. The primary parvovirus infection can aggravate the course of malaria, especially when combined with other unfavorable conditions (iron deficiency, malnutrition, helminthic infections, co-infections, etc.). Thus, infection with PVB19 becomes a critical factor, which can provoke a severe life-threatening anemia, and also cause other complications.
\end{abstract}

Key words: parvovirus infection, DNA of parvovirus B19, Plasmodium falciparum, malaria, anemia.

\section{ВЛИЯНИЕ КОИНФИЦИРОВАНИЯ РVВ19 И PLASMODIUM FALCIPARUM НА ТЕЧЕНИЕ И ПРОГНОЗ МАЛЯРИИ}

Лаврентьева И.Н. ${ }^{1}$, Хамитова И.В. ${ }^{1}$, Слита А.В. ${ }^{1}$, Левковский А.Е. ${ }^{2}$, Диало А.А. ${ }^{2}$, Диало А.К. ${ }^{2}$, Соу Т.С. ${ }^{2}$, Найденова Е.В. ${ }^{3}$, Агафонов Д.А. ${ }^{3}$, Сеничкина А.М. ${ }^{3}$

${ }^{1}$ ФБУН НИИ эпидемиологии и микробиологии имени Пастера, Санкт-Петербург, Россия

${ }^{2}$ Госпиталь «РУСАЛ» Боксито-глиноземного комплекса «Фригия», г. Фрия, Гвинейская Республика

${ }^{3}$ ФКУЗ Российский научно-исследовательский противочумный институт "Микроб" Роспотребнадзора, г. Саратов, Россия

Резюме. Парвовирусная инфекция (ПВИ) широко распространена в мире: более $80 \%$ взрослого населения имеют антитела класса G к парвовирусу В19. Малярия - трансмиссивное паразитарное заболевание, вызываемое

\author{
Адрес для переписки: \\ Лаврентьева Ирина Николаевна \\ 197101, Россия, Санкт-Петербург, ул. Мира, 14, \\ ФБУН НИИЭМ имени Пастера. \\ Тел.: 8 (812) 232-94-11 (служебн.); 8 (921) 341-05-01 (моб.). \\ E-mail: pasteur.lawr@mail.ru
}

\section{Библиографическое описание:}

Лаврентьева И.Н., Хамитова И.В., Слита А.В., Левковский А.Е., Диало А.А.,

Диало А.К., Соу Т.С., Найденова Е.В., Агафонов Д.А., Сеничкина А.М.

Влияние коинфицирования PVB19 и Plasmodium falciparum на течение

и прогноз малярии // Инфекция и иммунитет. 2018. Т. 8, № 3. С. 383-387.

doi: 10.15789/2220-7619-2018-3-383-387

\section{Contacts:}

Irina N. Lavrentieva

197101, Russian Federation, St. Petersburg, Mira str., 14,

St. Petersburg Pasteur Institute.

Phone: +7 (812) 232-94-11 (office); +7 (921) 341-05-01 (mobile). E-mail: pasteur.lawr@mail.ru

\section{Citation:}

Lavrentyeva I.N., Khamitova I.V., Slita A.V., Levkovski A.E., Diallo A.A., Diallo A.K., Sow T.C., Naydenova E.V., Agafonov D.A., Senichkina A.M. Impact of coinfection of PV B19 on the course and prognosis of malaria caused by Plasmodium falciparum // Russian Journal of Infection and Immunity = Infektsiya i immunitet, 2018, vol. 8, no. 3, pp. 383-387. doi: 10.15789/2220-7619-2018-3-383-387 
простейшим рода Plasmodium, широко распространенное в странах Африки, Юго-Восточной Азии, Океании. Целью работы было изучение влияния инфицирования парвовирусом В19 на клиническое течение малярии и исход основного заболевания. В период 2016-2018 гг. на наличие ДНК PVB19 исследованы образцы плазмы крови больных госпиталя префектуры Фрия Гвинейской Республики (ГР) с лабораторно подтвержденным диагнозом «малярия». Клиническое течение малярии у 316 обследованных пациентов оценивали как «простое» и «осложненное». В целом, ДНК PVB19 DNA была выявлена в плазме крови 55 из 316 пациентов $(17,41 \pm 2,13 \%)$. Но в группе больных с коинфицированием PVB19 и P. falciparum осложненное течение малярии наблюдали

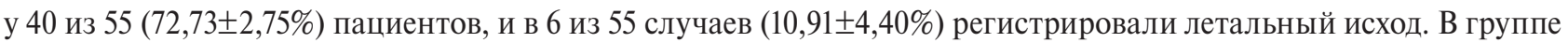
пациентов с малярией без коинфицирования парвовирусом В19 осложнения наблюдались у 99 из 261 пациента $(37,9 \pm 3,0 \%)$; из них $2(0,77 \pm 0,54 \%)$ умерли. Было обнаружено, что наиболее многочисленная группа в структуре

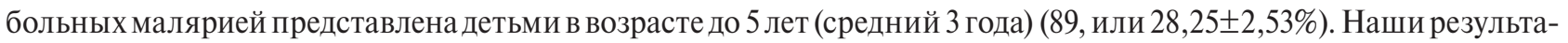
ты коррелируют с данными других исследователей: среди детей в возрасте до 5 лет, проживающих в районах, эндемичных по малярии, абсолютное большинство случаев парвовирусной инфекции сопровождалось осложненным течением малярии. Парвовирусная инфекция, развивающаяся в раннем детском возрасте, может усугублять течение малярии, особенно на фоне других неблагоприятных условий (дефицит железа, недоедание, гельминтные инвазии, коинфекции и пр.). При этом инфицирование PVB19 становится критическим фактором, который может провоцировать злокачественное течение анемии с угрозой для жизни, а также вызывать другие осложнения.

Ключевые слова: парвовирусная инфекция, ДНК парвовируса B19, Plasmodium falciparum, малярия, анемия.

\section{Introduction}

Parvovirus infection (PVI) is widespread in the world; more than $80 \%$ of the adult population have antibodies of IgG class to parvovirus B19 [6]. The causative agent of PVI is the DNA-containing parvovirus B19 (PVB19). PVB19 has a tropism for cells carrying $\mathrm{P}$-antigen (Gb4 receptor). These are the precursor cells of the erythroid bone marrow lineage, liver, spleen, heart and intestine tissues, mature erythrocytes, granulocytes, endothelial and smooth muscle cells of the vessels. Depending on the hematological and immunological status, the manifestations of PVI vary from asymptomatic course or mild exanthemic disease (infectious erythema) to severe forms (aplastic crisis, pancytopenia, acute hepatitis, fulminant hepatic failure, encephalitis, cardiomyopathy and myocarditis). Parvovirus infection complicates the course of diseases accompanied by immunodeficiencies (oncological, hematological, etc.) $[1,2,9]$. According to several authors, infection with PVB19 can aggravate the course of malaria [3, $8,12,14]$.

Malaria is a vector-borne parasitic disease caused by the protozoa of the genus Plasmodium, that is widespread in the countries of Equatorial Africa, Southeast Asia, Oceania, Central and South America. The problem of malaria is especially urgent for the Sub-Saharan Africa. This territory accounts for $90 \%$ of cases and $92 \%$ of deaths from malaria in the world. According to WHO, in the Republic of Guinea (GR) in 2015, 811000 cases of laboratory-confirmed malaria were detected. The disease proceeds with cyclic fever, febrile paroxysms, hepatorenal and anemic syndrome. Severe complications of malaria leading to death can be cerebral edema, cerebral (malarial) coma, splenic and kidney failure, disseminated intravascular coagulation syndrome (DIC-syndrome), acute massive hemolysis, hemoglobinuria, hemorrhagic syndrome.

The objective of the present study was to evaluate the effect of parvovirus B19 infection on the clinical course of malaria and the outcome of the underlying disease.

\section{Materials and methods}

During the period 2016-2018 blood plasma samples of 316 patients from the hospital of the Friya Prefecture of the Republic of Guinea (GR) with confirmed diagnosis of malaria were examined for the presence of PVB19 DNA. DNA PVB19 was detected by PCR using the sets of reagents Ampliprime "RIBOprep" and "AmpliSens ${ }^{\circledR}$ Parvovirus B19-FL" (Central Institution of Epidemiology, Rospotrebnadzor, Russia) in accordance with the manufacturer's instruction.

Statistical treatment of the results was carried out using the analysis of frequency distributions and conjugacy tables using the GraphPadInStat 3 software. The significance of the differences and the confidence interval were determined by the Student's t-test. Differences were considered significant at $\mathrm{p}<0.01$.

\section{Results}

The clinical course of malaria in 316 examined patients was divided into group of either mild or complicated. A mild course of malaria was detected in $177(56.01 \pm 2.79 \%)$ patients. This form of the disease was characterized by fever with temperature not exceeding $39^{\circ} \mathrm{C}$, general weakness and moderate anemia (hemoglobin concentration higher than 
Table 1. The effect of parvovirus B19 infecting on the course of malaria in patients of Fria Prefecture of the Republic of Guinea

\begin{tabular}{|c|c|c|c|}
\hline \multirow{2}{*}{ Course of malaria } & \multirow{2}{*}{ Number of patients, abs./\% } & \multicolumn{2}{|c|}{ Presence of PV19 DNA } \\
\cline { 3 - 4 } & & Positive, abs./\% & Negative, abs./\% \\
\hline Mild & $177 / 56.01 \pm 2.79$ & $15 / 27.27 \pm 2.75$ & $162 / 62.07 \pm 3.0$ \\
\hline Complicated & $139 / 43.99 \pm 2.79$ & $40 / 72.73 \pm 2.75$ & $99 / 37.93 \pm 3.0$ \\
\hline Lethal outcome & $8 / 2.53 \pm 0.88$ & $6 / 10.91 \pm 4.40$ & $2 / 0.77 \pm 0.54$ \\
\hline Total & $316 / 100$ & $55 / 17.41 \pm 2.13$ & $261 / 82.6 \pm 2.13$ \\
\hline
\end{tabular}

$70 \mathrm{~g} / 1) .139$ patients $(43.99 \pm 2.79 \%)$ manifested the complicated course of malaria that was accompanied by a rise of the temperature up to $40^{\circ} \mathrm{C}$, nausea, vomiting, severe anemia (hemoglobin concentration lower than $70 \mathrm{~g} / 1$ ), high levels of transaminases, creatinine, a decrease in the total protein in the blood. In $8(2.53 \pm 0.88 \%)$ cases, the severe course of the disease led to a fatal outcome.

Plasma samples of patients with mild and complicated forms of malaria were tested for the presence of PVB19 DNA. The results are shown in Table 1.

In total, PVB19 DNA was detected in blood plasma in 55 of 316 patients $(17.41 \pm 2.13 \%)$. In groups of both PVB19-positive and negative patients, cases of mild and complicated as well as fatal outcomes were detected. However, in the group with co-infection of PVB19 and P. falciparum, complications and mortality rates were significantly higher. Indeed, complications were observed in 40 of $55(72.73 \pm 2.75 \%)$ patients, and in 6 of 55 cases $(10.91 \pm 4.40 \%)$ the disease resulted in death. In the group of patients with malaria without PVI, complications occurred in 99 of 261 patients $(37.9 \pm 3.0 \%)$; of those $2(0.77 \pm 0.54 \%)$ died. Thus, the probability of developing a complicated course of malaria with a co-infection is significantly higher than in the absence of PVI $(p<0.0001$; $\mathrm{RR}=1.917$; $95 \% \mathrm{CI}: 1.532$ to 2.399$)$.

To study the age structure of patients with malaria, they were distributed into seven age groups: $0-5,6-10,11-15,16-25,26-45$ and $46-65$ years old (Table 2). It was found that the most numerous group in the structure of malaria patients is represented by children under 5 (median 3 ) years $(89$, or $28.25 \pm 2.53 \%$ ). The lowest number of malaria cases falls into the age group of 46-65 (median 57) years 17 cases, or $5.4 \pm 0.71 \%$. It is noteworthy that the DNA of PVB19 in the blood plasma of patients of this group has not been detected.

In other age groups of patients with malaria, the presence of PVB19 DNA in the blood plasma is characterized by the following rates: among children under 5 years (median 3 years) it was detected in $17.98 \pm 4.07 \%$ of patients; in the group of 6-10 years (median 8 years), the detection rate increased to $28.85 \pm 6.28$, and reached a maximum of $34.29 \pm 8.02 \%$ in the group of $11-15$ years (median 13 years). These results indicate a wide prevalence of parvovirus infection among children and adoles- cents and correspond to the data available in the literature $[5,13,15]$. In older patients, this value was reduced to $15.38 \pm 5.0 \%$ in the group of $16-25$ years (median 20 years), to $5.71 \pm 3.22 \%$ in the group of 26-45 years (median 36.5 years) and zero in the age group of 46-65 years (median 57 years). The severity of PVB19-associated malaria was analyzed in different age groups. The results are summarized in Table 3.

As can be seen from the results presented, the maximum number of cases of complicated malaria with PVI $(n=15)$ was observed in patients under 5 years old, where it accounts for $93.75 \pm 6.05 \%$ of cases comparing to $27.27 \pm 7.04 \%$ among all PVB19-positive patients. The likelihood of developing a complicated course of malaria with a co-infection in this age group is significantly higher than in the absence of PVI $(\mathrm{p}=0.0001 ; \mathrm{RR}=2.44 ; 95 \% \mathrm{CI}: 1.780-3.357)$. It is important to note that 6 out of 8 deaths occur in this group, that is significantly higher than in the absence of infection with PV B19 ( $\mathrm{p}=0.0003, \mathrm{R} R=13.688$, 95\% CI: 3.034-61.740). With age increase, the incidence of complicated course of PVI-combined malaria decreases, although the trend persists in individuals under 26 years of age. Thus, among patients of 6-10 years of age, complicated malaria was recorded in $18.18 \pm 5.75 \%$ of PV B19-infected persons; in the group of $11-15$ years - in $14.55 \pm 5.14 \%$ of cases; in persons from 16 to 25 years in $9.09 \pm 4.07 \%$ of cases. However, the differences in the course of malaria between patients infected and not infected with parvovirus B19 are not statistically reliable in all these age groups.

Table 2. Age distribution of malaria patients with combined parvoviral infection

\begin{tabular}{|c|c|c|}
\hline $\begin{array}{c}\text { Age group, } \\
\text { years }\end{array}$ & $\begin{array}{c}\text { Number of patients, } \\
\text { abs./\% }\end{array}$ & $\begin{array}{c}\text { PVB19-positive, } \\
\text { abs./\% }\end{array}$ \\
\hline $\mathbf{0 - 5}$ & $89 / 28.25 \pm 2.53$ & $16 / 17.98 \pm 4.07$ \\
\hline $\mathbf{6 - 1 0}$ & $52 / 16.51 \pm 2.09$ & $15 / 28.85 \pm 6.28$ \\
\hline $\mathbf{1 1 - 1 5}$ & $35 / 11.11 \pm 1.77$ & $12 / 34.29 \pm 8.02$ \\
\hline $\mathbf{1 6 - 2 5}$ & $52 / 16.51 \pm 2.09$ & $8 / 15.38 \pm 5.00$ \\
\hline $\mathbf{2 6 - 4 5}$ & $70 / 22.22 \pm 1.16$ & $4 / 5.71 \pm 3.22$ \\
\hline $\mathbf{4 6 - 6 5}$ & $17 / 5.40 \pm 0.71$ & $0 / 0.0$ \\
\hline Total & $315 / 100$ & $55 / 17.46 \pm 2.14$ \\
\hline
\end{tabular}


Table 3. Mild and complicated course of malaria associated with parvovirus B19 infection in different age groups

\begin{tabular}{|c|c|c|}
\hline Age, years & $\begin{array}{c}\text { Mild disease, } \\
\text { abs./\% }\end{array}$ & $\begin{array}{c}\text { Complicated } \\
\text { disease, abs./\% }\end{array}$ \\
\hline $\mathbf{0 - 5}$ & $1 / 1.82 \pm 1.80$ & $15 / 27.27 \pm 7.04$ \\
\hline $\mathbf{6 - 1 0}$ & $5 / 9.09 \pm 3.88$ & $10 / 18.18 \pm 5.75$ \\
\hline $\mathbf{1 1 - 1 5}$ & $4 / 7.27 \pm 3.50$ & $8 / 14.55 \pm 5.14$ \\
\hline $\mathbf{1 6 - 2 5}$ & $3 / 5.45 \pm 3.06$ & $5 / 9.09 \pm 4.07$ \\
\hline $\mathbf{2 6 - 4 5}$ & $2 / 3.64 \pm 2.52$ & $2 / 3.64 \pm 2.57$ \\
\hline $\mathbf{4 6 - 6 5}$ & $0 / 0.0 \%$ & $0 / 0.0 \%$ \\
\hline $\begin{array}{c}\text { Total } \\
\text { (n = 55) }\end{array}$ & $15 / 27.27 \pm 6.01 \%$ & $40 / 72.73 \pm 11.50 \%$ \\
\hline
\end{tabular}

\section{Discussion}

It is known that in seronegative individuals with primary infection parvovirus in the acute phase can cause a failure of erythrocytes formation for up to 5-7 days, which leads to a significant decrease in hemoglobin [15]. Erythrocytes are also the main target of the malarial plasmodium, which multiplies within and destroys them thus causing anemia of varying severity. According to several authors, infection with PVI occurs after decrease in cellular immunity caused by $P$. falciparum $[4,7]$. There is evidence that in severe malaria-endemic regions severe forms of anemia are the main cause of child mortality.
Thus, severe anemia is considered the cause of childhood death in malaria in $17-54 \%$ of cases [11, 13].

Our results correlate with the data of other researchers who studied the PVI-associated malaria in children in malaria-endemic regions: among children under 5 years, the absolute majority of cases of PVI was accompanied by a complicated course of malaria $[4,10,14]$.

Having in mind that according to studies, in African countries 50 to $90 \%$ of the population by age 6 have IgG antibodies to PVB19 [15] and, based on the results obtained, it can be assumed that the probability of complicated course of PVIassociated malaria depends on the age of the patient. The older the patient, the higher the probability of having immunity to parvovirus, and, therefore, the less influence the associated infection demonstrates.

In contrast, the primary parvovirus infection, which normally occurs in early childhood, is acute and can aggravate the course of malaria, especially when combined with other unfavorable conditions (iron deficiency, malnutrition, helminthic infections, co-infections, etc.). Thus, infection with PVB19 becomes a critical factor, which can provoke a severe life-threatening anemia, and also cause other complications.

In general, the results of this study indicate a high medical-social significance of parvovirus infection for countries endemic for malaria.

\section{Список литературы/References}

1. Лаврентьева И.Н., Антипова А.Ю. Парвовирус В19 человека - характеристика возбудителя и распространение обусловленной им инфекции // Инфекция и иммунитет. 2013. Т. 3, № 4. C. 311-322. [Lavrentyeva I.N., Antipova A.Yu. Human parvovirus B19: virus characteristics, distribution and diagnostics. Infektsiya i immunitet $=$ Russian Journal of Infection and Immunity, 2013, vol. 3, no. 4, pp. 311-322. doi: 10.15789/2220-7619-2013-4-311-322(In Russ.)]

2. Лаврентьева И.Н., Антипова А.Ю., Бичурина М.А., Семенов А.В. Генотипирование изолятов парвовируса В19, циркулирующих в Северо-Западном федеральном округе России // Журнал микробиологии, эпидемиологии и иммунобиологии. 2013. № 6. С. 36-43. [Lavrentyeva I.N., Antipova A.Yu., Semenov A.V., Ostankova Yu.V., Bichurina M.A. Parvovirus B19 stains genotyping as exanthematous diseases epidemiological surveillance improvement in Russia. Zhurnal mikrobiologii, epidemiologii i immunobiologii = Journal of Microbiology, Epidemiology and Immunobiology, 2013, no. 6, pp. 36-43. (In Russ.)]

3. Agarwal R., Baid R., Datta R., Saha M., Sarkar N. Falciparum malaria and parvovirus B19 coinfection: a rare entity. Trop. Parasitol., 2017, vol. 7(1), pp. 47-48. doi: 10.4103/2229-5070.202299

4. Duedu K.O., Sagoe K.W., Ayeh-Kumi P.F., Affrim R.B., Adiku T., Huat L.B. The effects of co-infection with human parvovirus B19 and Plasmodium falciparum on type and degree of anaemia in Ghanaian children. Asian Pac. J. Trop. Biomed., 2013, vol. 3, no. 2, pp. 129-139. doi: 10.1016/S2221-1691(13)60037-4

5. Florea A.V., Ionescu D.N., Melhem M.F. Parvovirus B19 infection in the Immunocompromised host. Arch. Pathol. Lab. Med., 2007, vol. 131, pp. 799-804. doi: 10.1043/1543-2165(2007)131[799:PBIITI]2.0.CO;2

6. Heegaard E.D., Brown K.E. Human parvovirus B19. Clin. Microbiol. Rev., 2002, vol. 15, pp. 485-505. doi: 10.1128/CMR.15.3.485505.2002

7. Ho M., Webster H.K., Looareesuwan S., Supanaranond W., Phillips R.E., Chanthavanich P., Warrell D.A. Antigen-specific immunosuppression in human malaria due to Plasmodium falciparum. J. Infect. Dis., 1986, vol. 153, pp. 763-771.

8. Ingrassia F., Gadaleta A., Maggi P., Pastore G. Plasmodium falciparum malaria and Parvovirus B19; a case of acute co-infection. BMC Infect. Dis., 2010, vol. 10, p. 87. doi: 10.1186/1471-2334-10-87

9. Jitschin R., Peters O., Plentz A., Turowski P., Segerer H., Modrow S. Impact of parvovirus B19 infection on paediatric patients with haematological and/or oncological disorders. Clin. Microbiol. Infect., 2011, vol. 17, no. 9, pp. 1336-1342. doi: 10.1111/j.14690691.2010.03355.x

10. Manning L., Laman M., Rosanas-Urgell A., Michon P., Aipit S., Bona C., Siba P., Mueller I., Davis TM. Severe anemia in Papua New Guinean children from a malaria-endemic area: a case-control etiologic study. PLoS Negl. Trop. Dis., 2012, vol. 6, no. 12: e1972. doi: 10.1371/journal.pntd.0001972 
11. Newton C.R., Warn P.A., Winstanley P.A., Peshu N., Snow R.W., Pasvol G., Marsh K. Severe anaemia in children living in a malaria endemic area of Kenya. Trop. Medicine \& International Health, 1997, vol. 2, no. 2, pp. 165-178. doi: 10.1046/j.1365-3156.1997. d01-238.x

12. Scarlata F., Gianelli E., Miceli S., Galimberti L., Antinori S. Acute parvovirus B19 infection and anemia during Plasmodium falciparum malaria. Clin. Infect. Dis., 2002, vol. 35, no. 11, pp. 1449-1451. doi: 10.1086/344452

13. Slutsker L., Taylor T.E., Wirima J.J., Steketee R.W. In-hospital morbidity and mortality due to malaria-associated severe anaemia in two areas of Malawi with different patterns of malaria infection. Trans. R. Soc. Trop. Med. Hyg., 1994, 88, 548-551.

14. Toan N.L., Sy B.T., Song L. H., Luong H. V., Binh N. T., Binh, Vu Q., Kandolf R., Velavan T.P., Kremsner P.G., Bock C.-T. Coinfection of human parvovirus B19 with Plasmodium falciparum contributes to malaria disease severity in Gabonese patients. $B M C$ Infect. Dis., 2013, vol. 13: 375. doi: 10.1186/1471-2334-13-375

15. Wildig J., Cossart Y., Peshu N., Gicheru N., Tuju J., Williams T.N., Newton C.R. Parvovirus B19 infection and severe anaemia in Kenyan children: a retrospective case control study / BMC Infect. Dis., 2010, vol. 10: 88. doi:10.1186/1471-2334-10-88

16. Wildig J., Michon P., Siba P., Mellombo M., Ura A., Mueller I., Cossart Y. Parvovirus B19 infection contributes to severe anemia in young children in Papua New Guinea. J. Infect. Dis., 2006, vol. 194, no. 2, pp. 146-153. doi: 10.1086/505082

\section{Авторы:}

Лаврентьева И.Н., д.м.н., зав. лабораторией экспериментальной вирусологии ФБУН НИИ эпидемиологии и микробиологии имени Пастера, Санкт-Петербург, Россия;

Хамитова И.В., зав. Центральной клинико-диагностической лабораторией ФБУН НИИ эпидемиологии и микробиологии имени Пастера, Санкт-Петербург, Россия;

Слита А.В., к.б.н., старший научный сотрудник лаборатории экспериментальной вирусологии ФБУН НИИ эпидемиологии и микробиологии имени Пастера, Санкт-Петербург, Россия; Левковский А.Е., руководитель госпиталя «Русал» бокситоглиноземного комплекса «Фригия», г. Фрия, Гвинейская Республика;

Диало А.А., главный врач госпиталя Русал БГК «Фригия», г. Фрия, Гвинейская Республика;

Диало А.К., зав. лабораторией госпиталя Русал БГК «Фригия», г. Фрия, Гвинейская Республика;

Coy T.C., врач-лаборант госпиталя Русал БГК «Фригия», г. Фрия, Гвинейская Республика;

Найденова Е.В., к.б.н., старший научный сотрудник отдела диагностики инфекционных болезней ФКУЗ Российский научно-исследовательский противочумный институт «Микроб» Роспотребнадзора, г. Саратов, Россия;

Агафонов Д.А., к.б.н., старший научный сотрудник отдела микробиологии ФКУЗ Российский научно-исследовательский противочумный институт «Микроб» Роспотребнадзора, г. Саратов, Россия;

Сеничкина А.М., к.б.н., научный сотрудник отдела диагностики инфекционных болезней ФКУЗ Российский научноисследовательский противочумный институт «Микроб» Роспотребнадзора, г. Саратов, Россия.

\section{Authors:}

Lavrentyeva I.N., PhD, MD (Medicine), Head of Laboratory of Experimental Virology, St. Petersburg Pasteur Institute, St. Petersburg, Russian Federation;

Khamitova I.V., Head of Central Clinical Diagnostic Laboratory, St. Petersburg Pasteur Institute, St. Petersburg, Russian Federation; Slita A.V., PhD (Biology), Senior Researcher, Laboratory of Experimental Virology, St. Petersburg Pasteur Institute, St. Petersburg, Russian Federation;

Levkovski A.E., Head of the Hospital RUSAL FRIGUIA, Fria, Republic of Guinea;

Diallo A.A., Head Physician, Hospital RUSAL FRIGUIA, Fria, Republic of Guinea;

Diallo A.K., Head of the Laboratory, Hospital RUSAL FRIGUIA, Fria, Republic of Guinea;

Sow T.C., Laboratory assistant Hospital RUSAL FRIGUIA, Fria, Republic of Guinea

Naydenova E.V., PhD (Biology), Senior Researcher, Department of Diagnostics of Infectious Diseases, Russian Research Anti-Plague Institute "Microbe", Saratov, Russian Federation;

Agafonov D.A., PhD (Biology), Senior Researcher, Department of Microbioilogy, Russian Research Anti-Plague Institute "Microbe", Saratov, Russian Federation;

Senichkina A.M., PhD (Biology), Senior Researcher, Department of Diagnostics of Infectious Diseases, Russian Research Anti-Plague Institute "Microbe", Saratov, Russian Federation. 